and public relations for both travellers and local residents.

Heathrow, Gatwick, Stansted and Prestwick-the four international airports formerly owned by the Ministry of Aviation-were handed over to the authority in April 1966. They represent a small proportion of the eighteen airports in Britain with scheduled services, but between them they handle 60 per cent of the total passenger traffic. Gatwick, struggling with seasonal traffic problems, could not balance its winter deficits by its summer profits. Stansted, on the brink of development, also failed to produce an operating surplus. Prestwick succeeded, however, and Heathrow, handling more international passengers than any other airport in the world, made enough for the authority to record a net profit before tax of $£ 2.7$ million.

Prestwick, owned by the authority, is as yet less busy than Abbotsinch, the other airport in Glasgow which is owned by the city. The two are being developed side by side, however; Prestwick, with tartan trimmings and welcoming early morning music, is to concentrate on long distance intercontinental flights, leaving short hauls and domestic routes to Abbotsinch.

Although the authority seems to have started well, there is as yet little talk of its taking on any other airports. The Board of Trade runs several airports and the rest, apart from a few private ones, are municipally owned. Not all of them are making a profit and, unless there is a chance of financial viability, it is unlikely that the authority will be able to take them on. Talks are at present going on, however, between the authority and the Board of Trade about the future of Edinburgh airport which the city council has declined to look after. The authority is building up a specialized staff of airport developers, and is prepared to act on a consultancy basis if its advice is sought.

\section{Death of an Elephant}

The post-mortem on Diksie, the London Zoo's twentyseven year old African elephant which died last week after falling into the dry moat around her enclosure, has revealed that she had serious injuries from which she could not have recovered. The main nerve of the left front leg was severed - a result of the way in which she fell and landed off balance. Her right tusk was broken, and she was concussed-she hit her head on the front wall of the moat. With injuries such as these nothing could have been done to save the four ton elephant. The zoo's lifting equipment could have lifted her into a standing position had she not been injured. With her damaged leg it would have been necessary to destroy the elephant even if the rescue operation had been successful.

Elephants have fallen before during the past twenty years. In her previous enclosure Diksie fell into the moat, which was deeper than the present one, and was removed safely. An Indian elephant has also fallen into the same moat in which Diksie died, but was unhurt and was brought out with little difficulty. Last week's was the first fatality, the result of an awkward fall.

The zoo says that it has no reason to doubt the efficiency of the moat. It is, however, considering banning all feeding of elephants by the public, because the animals would not then be encouraged to stand at the edge of the moat and stretch out their trunks to catch items of food. It was this that was partly responsible for Diksie's fall. A ban on feeding, with warning notices and constant supervision by staff, works effectively in continental zoos, and its introduction in London would not be untimely.

\section{Software for Teaching}

Educational technology sounds like a grand name for teaching machines, but in fact it includes a great deal more than hardware. Closed circuit television and language laboratories cannot work by themselves, and the provision of the right programmes for such machines is a task which is receiving increasing attention. On a more fundamental level, research is now being done to find the best use for each type of machine and the most effective means of using the machines in teaching actual subjects. The creation of the National Council on Educational Technology is a sign of the times.

The latest group to take up this type of work in Britain is the newly established Institute for Educational Technology at the University of Surrey. Professor L. R. B. Elton, head of the physics department, will be taking charge of the institute, which he believes to be the first of its kind in Britain concentrating on teaching aids in universities. The Massachusetts Institute of Technology has such a department, but most of the work on audio-visual aids in Britain, at Leeds and Sussex, for example, has been for the secondary school level.

The new institute at Surrey will be working in close touch with the several departments in the university, and Professor Elton hopes that this unusual relationship, which will link the educational research directly with the teaching methods in use in each subject, will prove fruitful. The teaching of first year students is one of the first important areas for investigation, and this will be studied in connexion with sixth form teaching, as the two are so closely related.

In the present buildings in Battersea there is little room for the institute to take on students, but when the university moves to Guildford in 1968 it is hoped that students will be able to take higher degrees in this expanding field. Students who can take postgraduate courses in educational technology will be well equipped to raise standards when they begin to teach. Studies of this nature may also encourage more science students to apply themselves to teaching. The institute hopes also to encourage school teachers in the area to join in this work so that the results of research can be put into practice.

A grant of $£ 1,350$ has been awarded to the Institute by the Social Science Research Council for a particular project concerned with the transition between school and university. Philips Industries has offered support, particularly in the form of machinery, and other finances are being provided through the usual university channels.

\section{Brakes without Skids}

A Recent study by Mr J. K. Meades of the Road Research Laboratory shows that different tread patterns have only a small effect on braking efficiency on wet roads. Mr Meades tested five different cross ply 